\title{
Dual Oxidase 2 Deficiency
}

National Cancer Institute

\section{Source}

National Cancer Institute. Dual Oxidase 2 Deficiency. NCI Thesaurus. Code C121748.

Thyroid peroxidase system defect due to presumed mutation(s) in the DUOX2 gene, resulting in decreased activity of dual oxidase 2 . 